conducted outside the scientific forum", that is, in all dealings with the public.

Let us compare the two 'victim' populations. Each specialist science community is fully equipped and prepared to detect fraud (or honest error) in any paper. But the public is utterly defenceless against any exaggerated claim or hype, however egregious. Moreover, there may be enormous public consequences, such as the misdirection of billions of dollars resulting from such fraud or scientific misconduct because it influences the public.

It is also not possible for scientists to blame journalists for exaggerating their claims, unless they publicly disown them when they appear. I submit that all persons or bodies thinking about scientific misconduct should concern themselves first with the ethics of our behaviour when we deal with the public.

\section{Rustum Roy}

102 Materials Research Laboratory,

Pennsylvania State University, University Park, Pennsylvania 16802-4801, USA

\section{Question marks over} \section{genetic counselling}

Sir - Perhaps the high tide of genetic determinism in all things biological is beginning to recede a little at last. I was relieved to read of the caution advised by the UK bioethics committee with regard to genetic screening as a means of predicting the susceptibility of individuals to mental disorders (Nature 395, 309; 1998).

Even the most fervent supporters of the contentious idea that there is a significant genetic component to mental disorders would probably be prepared to admit that the correlation between the occurrence of a gene and that of a disorder in these cases is statistical. There are plenty of people with the gene, but not the disorder, and plenty of others with the disorder, but not the gene. This is also true of the much publicized genes 'for' heart disease and breast cancer, among others.

What does the individual do with the knowledge that they carry such genes and what advice can genetic counsellors give them? Don't smoke, don't drink too much, be careful about what you eat, take a little exercise, avoid stress and, you there with that gene, even more so? This is stretching the concept of genetic determinism beyond utility.

At a recent conference on the commercial potential of genomics I heard a representative of those who wish to offer such screening to all individuals on a commercial basis concede that their counsellors sometimes had difficulty in communicating the importance of the information to the recipients. He appeared to think that this was a problem of education and perhaps he was right, though the problem may be his, not theirs. The recipients may have been sufficiently well educated to realize that statistics are properties of populations, not individuals, and, even if the assumptions about the genetic component of the disease were actually correct, the information they were receiving was absolutely useless to them.

Alan Akers

120 Avenue de Strasbourg,

67170 Brumath, France

\section{Germany keen to reduce} the nuclear threat

Sir - The German government is keenly interested in diminishing the dangers arising from the enormous stocks of plutonium no longer required for nuclear weapons and still held by certain states. It has taken an active part in all efforts to find ways of finally disposing of this material and is well acquainted with the ideas put forward by Frank N. von Hippel in your Commentary, "How to simplify the plutonium problem" (Nature 394, 415-416; 1998).

I categorically reject the author's outrageous and totally spurious charge that Germany has "pursued the development of nuclear weapons under the cover of 'civilian' plutonium programmes". I refute his association of Germany with nuclear pariah states such as Iraq, North Korea or Pakistan and his insistence that "the danger is not past". Comments of this nature fly in the face of all Germany's declarations, commitments and treaty obligations since its accession to the Western European Union and the North Atlantic Treaty Organization as well as the Nuclear NonProliferation Treaty.

Moreover, they completely disregard decades of Euratom and International Atomic Energy Agency reports and safeguards inspections confirming the absolutely peaceful character of Germany's activities in nuclear research and power generation. These allegations are entirely devoid of foundation.

\section{Martin Erdmann}

Federal Foreign Office,

Auswärtiges Amt, Postfach 1148,

53001 Bonn, Germany

Frank N. von Hippel replies - I included Germany (and Sweden) in a long list of countries which I said "have all pursued the development of nuclear weapons under the cover of 'civilian' plutonium programmes". The following sentence began:
"Fortunately, internal political changes and external pressures have aborted most of these programmes...".

Germany and Sweden both abandoned their nuclear-weapons programmes before they signed the non-proliferation treaty of 1970 , almost 30 years ago. I am sorry that the reader misunderstood me as impugning Germany's — or Sweden's subsequent faithful adherence to that treaty. That was not my intention.

Similarly, my phrase that the "danger is not past" was not aimed at Germany. Indeed, the next sentence discusses the danger that the spread of reprocessing in east Asia could exacerbate the danger of proliferation there.

Frank N. von Hippel

Center for Energy and Environmental Studies, H-102 Engineering Quadrangle,

Princeton University,

Princeton, New Jersey 08544, USA

\section{'No controversy' atCITES}

Sir - I wish to comment on your article about the Convention on International Trade in Endangered Species (Nature 394, $112 ; 1998)$. The CITES secretariat is not "one of the United Nations' most controversial secretariats", but rather quite the contrary. For 25 years, it has been a model of efficiency and qualified service.

Your statement that "two members of the CITES secretariat in Geneva have been dismissed" is incorrect. The staff in question opted for early retirement, and were offered compensation for their long years of service. The departure of these two professional staff members is highly regretted.

You refer to the role of these two individuals "in awarding permits to organizations that wanted to trade in plants and animals on the CITES list of banned species". But the CITES secretariat does not grant CITES permits; this is the role of the CITES management authorities of member states. Permits are not granted to "organizations". Nothing of this sort ever happened in the secretariat, either related to these two staff members or, to my knowledge, to any other member of the secretariat.

The statements in your article have damaged the reputation of two honourable and highly skilled professionals, who have left the secretariat to the regret of all the parties, and who are very much respected by all who have known them. They are also damaging to the CITES parties, and to the United Nations Environment Programme. Victoria Lichtschein

Dirección de Fauna y Flora Silvestres,

Secretaría de Recursos Naturales y Desarrollo Sustentable, Argentina 